\title{
The Problem with "Community" in the Mental Health Field
}

[French translation: La problématique de la « communauté » dans le domaine de la santé mentale]

\author{
Tyler Frederick \\ University of Ontario Institute of Technology \\ Lesley A. Tarasoff \\ University of Toronto \\ Jijian Voronka \\ University of Windsor \\ Lucy Costa \\ Empowerment Council, Centre for Addiction and Mental Health \\ Sean Kidd \\ Centre for Addiction and Mental Health and University of Toronto
}

[La version française suit.]

\begin{abstract}
The concept of "community" is ubiquitous in mental health policy, research, and practice in Canada; however, its meaning is rarely defined. In this paper, we consider the positioning of "community" within the Canadian historical and political mental health context and reveal that it contrasts with the lived experiences of people with psychiatric disabilities. We argue that mental health policy, research, and practice should move away from the term community in favour of a framework that addresses basic needs, disability justice, intersecting social identities, and the structural forces that impact the lives of people with psychiatric disabilities as they "recover" in settings outside of hospital.
\end{abstract}

Keywords: Community, community participation, mental health, social inclusion, neoliberalism

Tyler Frederick, Faculty of Social Science and Humanities, University of Ontario Institute of Technology, Oshawa, Ontario; Lesley A. Tarasoff, Dalla Lana School of Public Health, University of Toronto, Toronto, Ontario; Jijian Voronka, School of Social Work, University of Windsor, Windsor, Ontario; Lucy Costa, Empowerment Council, Centre for Addiction and Mental Health, Toronto, Ontario; Sean Kidd, Centre for Addiction and Mental Health and Department of Psychiatry, University of Toronto, Toronto, Ontario.

The authors would like to thank all of the participants in the research, as well as members of the research team and members of the Empowerment Council at CAMH for their invaluable assistance with the larger research project. The research was supported by the Ontario Mental Health Foundation and the CAMH Foundation.

Correspondence concerning this article should be sent to Tyler Frederick, Faculty of Social Science and Humanities, University of Ontario Institute of Technology, 2000 Simcoe St. North, Oshawa, ON L1H 7K4. Email: tyler.frederick@uoit.ca 


\section{RÉSUMÉ}

Le concept de « communauté » est omniprésent dans les politiques, la recherche et la pratique en santé mentale au Canada. Malgré tout, sa signification est rarement définie. Dans le présent article, nous considérons le positionnement de la «communauté » dans le contexte historique et politique de la santé mentale au Canada, et nous révélons que celle-ci contraste avec les expériences vécues par les personnes ayant une incapacité psychiatrique. Nous soutenons que les politiques, la recherche et la pratique en matière de santé mentale devraient s'éloigner de la notion de communauté en faveur d'un cadre conceptuel qui tient compte des besoins fondamentaux, de la justice pour les personnes ayant une incapacité, des identités sociales intersectées et des forces structurelles qui influent sur la vie des personnes ayant une incapacité psychiatrique, et ce, au fur et à mesure que celles-ci se « rétablissent » à l'extérieur du milieu hospitalier.

Mots clés : communauté, participation communautaire, santé mentale, inclusion sociale, néolibéralisme

The concept of "community" is ubiquitous in mental health policy, research, and clinical practice in Canada; however, its meaning is rarely articulated or clearly defined. In this paper, we consider how the concept has been positioned both historically and in recent years, with a particular focus on the mental health strategy articulated by the Mental Health Commission of Canada (MHCC) (2009, 2012). Drawing on interviews with people with psychiatric disabilities that explore their views of community and its significance in their lives, we show how the concept of community in mental health policy, research, and clinical practice contrasts with the lived experiences of this population. Specifically, we found that community as conceived professionally in the mental health sector is not a meaningful construct in the lives of people with psychiatric disabilities.

Instead, discussions of community life with participants focused heavily on the limiting effects of poverty. From these data as well as the historical and theoretical work of service users themselves, we argue that mental health policy, research, and clinical practice should move away from the term community in favour of a framework informed by disability justice, focused on addressing barriers to basic needs (e.g., housing), and able to acknowledge intersecting social identities and the structural forces that impact the lives of people with psychiatric disabilities as they "recover" in settings outside of hospital.

\section{"Community" in the Mental Health Field}

The concept of community in the treatment of mental health problems has a long history in the West that includes ideas about healing communities in 14th-century Belgium and the "moral treatment" of the Quakers from the 18th century (Kennard, 2008). The healing power of social relationships and the health impacts of the social and physical environment were central to these perspectives (Kennard, 2008). These early ideas laid the foundation for the rise of the asylum as a treatment paradigm throughout the 19th and early 20th centuries. The asylum was imagined as a community and therapeutic refuge where a person with mental illness would receive the peace and care that they needed to recover. In reality, however, the asylums and institutions of the 18th and 19th centuries were more likely to be places of segregation and dehumanization than refuge (Davis, 2014; Mulvale, Abelson, \& Goering, 2007; Reaume, 2000; Regehr \& Glancy, 2014). 
Beginning in the mid-20th century, the ideals of the asylum (no matter how poorly realized) were further undermined and eroded by the growing medicalization of mental illness and reliance on the newly emerging pharmaceuticals for treating diagnoses such as schizophrenia and psychosis. This trend led to a focus on the biological basis of mental illness and less emphasis on the therapeutic value of community in the treatment of those with psychiatric disabilities (Novella, 2010). The shift towards medicalization, and a corresponding bureaucratization in the institutions of the 1960s, helped spur critiques of the asylum model from inside and outside the mental health system (Goering, Wasylenki, \& Durbin, 2000; Grob, 1995; Scull, 2015). Mental health service users were also organizing themselves to speak out about the troubling discourses and practices of psychiatry (Usar, 2014).

Central to the growing critique of psychiatric institutions in Canada and the United States was a new vision of community that emphasized the therapeutic value of including people with psychiatric disabilities in the "community" outside of the institution. The optimism behind this turn towards community-based mental health services is captured in U.S. President John F. Kennedy's 1963 speech about the Community Mental Health Act, in which he describes how the "cold mercy of custodial isolation" will be replaced with "the open warmth of community concern and capability" (Kennedy, 1963). Similar ideas were captured in a 1963 report published by the Canadian Mental Health Association, More for the Mind, which made a case for integrating mental health services within the hospital system as a means of transitioning away from custodial care, minimizing "dislocation," and maintaining as much "continuity and social restoration as possible" (Canadian Mental Health Association, 1963, p. 40).

Unfortunately, in Canada and the United States, this early model of community-based mental health was never realized (Davis, 2014). At the same time as this push arose towards providing services outside of psychiatric hospitals, economic and political forces were leading to a rapid downsizing of those hospitals without the corresponding creation of the community-based services meant to take their place (Davis, 2014; Grob, 1995; Novella, 2010). In Canada, the number of psychiatric hospital beds decreased by over $60 \%$ between 1960 and 1976, but spending on community-based services during the subsequent years remained comparatively low, such that by 1990 funding for community-based mental health services accounted for only $3 \%$ of provincial mental health budgets (Goering et al., 2000). These processes are known collectively as deinstitutionalization, and its failures are well documented, including high rates of homelessness, poverty, unemployment, victimization, public stigma, and social isolation for people with psychiatric disabilities (Davis, 2014; Grob, 1995; Regehr \& Glancy, 2014).

\section{A Place Out There: Neoliberal Communities}

Despite the failures of the deinstitutionalization era in Canada, community remains a central concept in mental health policy, clinical practice, and research. Notwithstanding the passage of over 50 years, however, and its uptake in prominent policy discourses, the concept often goes undefined and retains its 1960s image as a vaguely conceived place of promise outside the institution that offers belonging and inclusion for all those who live there.

An example of how the term community is deployed at a policy level in Canada is exemplified in the Mental Health Commission of Canada's $(2009,2012)$ national mental health framework. In the two versions 
of the strategy the term community is used over 200 times without being formally defined or operationalized. Furthermore, community is described as a physical and geographical space, outside of an institution, that offers inherent opportunity for belonging, echoing the 1960s ideals outlined above. The 2009 framework document states, for example, "Building on individual, family, cultural, and community strengths, people are empowered and supported to be actively engaged in their own journey of recovery and well-being, and to enjoy a meaningful life in their community while striving to achieve their full potential" (p. 20; emphasis added). Here, community is a decontextualized "place out there" with intrinsic potential for belonging, and in which people have the opportunity to strive towards self-improvement. This image mirrors a neoliberal vision of community that is at the heart of the gradual restructuring of the state through the solidification of neoliberal values, a process that has been occurring in Canadian public policy (and elsewhere) over the last 30 years.

Neoliberalism involves a shift towards a smaller government with the state acting as a coordinator and facilitator of various community-based social welfare initiatives rather than as a central provider and guarantor of social welfare. Neoliberalism includes not only the ways in which policy directives are produced and managed, but also the ways in which neoliberal values of independence, cost-efficiency, and austerity permeate ideological value constructions and modes of governance (see Larner, 2000). Key to neoliberal modes of governance and ideology are that individuals are expected to learn to self-manage their troubles and that those who fail to do so are implicitly framed as less valuable as citizens and as threats to social order.

The notion of communities as a naturally occurring alternative to the exclusion and marginalization of individuals with psychiatric disabilities shifts the responsibility for inclusion onto communities and individuals and does not attend to systemic issues such as sanism, racism, and poverty that impact the ability of individuals to choose how and where they live and to participate in community life. To this point, in the same 242 pages of the strategy (Mental Health Commission of Canada, 2009, 2012) where community is mentioned over 200 times, poverty is mentioned fewer than 25 times, and racism fewer than 10 times. Furthermore, poverty is largely discussed as a risk factor for poor mental health, and there is little discussion of the significant role poverty plays in organizing the lives of people with psychiatric disabilities. Further still, as Morrow and Weisser (2012) and Poole (2011) have described, the emphasis on "mental health recovery" in the last decade has led to greater emphasis on biomedicalization as opposed to discussions of social inequity. This is important insofar as "recovery" is a prominent theme in both strategic documents and is now readily coupled with conceptions of community wherein "the community" is conceptualized as the primary place where patients recover.

Compared to the 2009 framework document, the most recent MHCC document (2012) includes a more specific discussion of community and of systemic barriers such as housing, employment, and discrimination in its strategic directions for a transformed community mental health system. The 2012 document also includes recommendations to adopt a rights framework to do more to address diversity, and to better include the voice of those with mental illness in the planning and provision of community mental health services. The 2012 document also proposes a list of outcome measures, including systemic indicators such as increased employment rates and more affordable housing.

Despite these encouraging steps, however, the notion of community often retains its vague, presumptive, and optimistic image. For example, in discussing mental health services, the 2012 document states, "Supporting 
choice, conveying hope, and reducing the use of seclusion and restraint will contribute to ensuring successful transitions to a meaningful life in the community" (p. 65). This statement echoes the optimism of John F. Kennedy's 1963 speech that hope, choice, and not being confined in a hospital are sufficient for ensuring belonging and a meaningful life in the community. Furthermore, as Smith (2006) has noted, the rhetoric of choice is often invoked in neoliberal discourse to imply that individuals are filled with "free choice." The choice paradigm, argues Smith, "rests on essentially individualist, consumerist notions of 'free' choice that do not take into consideration all of the social, economic and political conditions that frame the so-called choices" that we are forced to make (p. 127).

The use of community in the MHCC's 2012 document does not unpack the impact of downloading responsibility from the state onto individuals and communities, and in turn does not fully address systemic barriers and discrimination. Emphasizing the responsibility that "communities" have for supporting recovery, for example, the document says,

At the individual and community levels, there are many things that can be done to protect and improve mental health. Some of the simple steps that can be easily integrated into our daily activities - such as making a conscious effort to connect with people around us, being physically active or doing something to help someone else - have been shown to contribute to our individual mental well-being. We also need to work to create healthier communities and reduce barriers that can inhibit individuals from acting to foster better mental health. For example, improving access to recreation for low-income families can help them to be physically active. (p. 22)

This statement exemplifies the complexity of the discourse that surrounds community, as we see the responsibilization of communities and individuals intertwined with reference to systemic problems. While the acknowledgement of systemic barriers for low-income families is valuable, where the emphasis is being placed should be questioned. In the document, the acknowledgement of barriers is framed as a secondary issue and discussed in abstract terms, providing little guidance on how to concretely address such barriers. Further, statements about what communities and individuals can do detracts from the fundamental systemic problem at the heart of the issue being described: poverty. Owing to the multifaceted ways that poverty shapes and organizes daily life, low-income families face complex barriers to accessing leisure opportunities that are hard to fully address through access initiatives (e.g., lack of time to allocate to finding appropriate programs, not having the proper clothes or equipment, stigma and discrimination from peers and staff).

To provide another example, the 2012 MHCC document references guidelines from Psychosocial Rehabilitation Canada (2010), emphasizing the role that communities can play in the recovery process. These guidelines suggest that the community be evaluated as an active participant in the recovery process: "Individuals, family as defined by the individual and the community, where appropriate, are involved in the planning, implementation and evaluation of the psychosocial rehabilitation support service" (p. 12). However, these guidelines do not specify how community is being defined, what it would mean for a community to be involved in the planning and implementation of an individual's recovery, how that involvement would be gauged or measured, or how a community could be compelled to be more active if it was found not to be playing an active role.

Neoliberal conceptions of community are reflected not only in policy documents like the MHCC strategy; they are also particularly visible in the ways that community, community integration, and community 
participation are measured and understood in the mental health and human services research literature. These conceptualizations are important because they shape and are shaped by how services are provided and how those with psychiatric disabilities are understood and evaluated by clinicians and researchers. In her review, Royce-Davis (2001) identifies three main ways community or community integration are conceptualized in the human services research literature: (a) community as a purely physical presence; (b) community as skills for independent community living; and (c) community as measured through proxies like employment status or number of rehospitalizations. Such measures reflect and underwrite the image of the neoliberal community as they emphasize self-reliance and employment, suggesting that integration is merely about living independently in the community.

Researchers have more recently attempted to develop a more nuanced conceptualization and measurement of community that challenges a geographically bound vision of community and instead emphasizes its multiple dimensions, including its physical, social, political, financial, and psychological components (Aubry, Flynn, Virley, \& Neri, 2013; Farone, 2006; Royce-Davis, 2001). Arguably, however, we need to hear more from those with psychiatric disabilities to really understand what community means and how it may or may not facilitate "recovery." From our interviews with an ethnically diverse group of people with psychiatric disabilities, we found that notions of community and belonging are more complex than the neoliberal utopian vision of local neighbourhoods or towns as places with inherent potential for belonging.

\section{METHODS}

\section{Exploring Community}

The following analysis draws on interviews with a diverse group of people with psychiatric disabilities. Specifically, as part of a larger study exploring meanings of community and experiences of community participation among people with psychiatric disabilities (Kidd et al., 2016), we interviewed 31 individuals who had a diagnosis of schizophrenia or a psychosis spectrum major mental illness and were living in one of five diverse inner-city neighbourhoods in downtown Toronto, Ontario. The interviews were conducted from September 2012 to December 2013. With the help of service providers in a variety of settings (hospital, community service, boarding home), we recruited individuals from neighbourhooods that were ethnically diverse and where large numbers of people with psychiatric disabilities are housed.

We sought to recruit a purposive sample in line with the main ethnocultural groups in the target neighbourhoods, which included African-Caribbean, South Asian, White European, and East Asian backgrounds. Highlighting the experiences of people belonging to these diverse ethnoracial groups was an important objective, as ethnoracial diversity is poorly reflected in the community and recovery literature (Kalathil \& Faulkner, 2015; Kidd, 2013). Furthermore, for all subgroups we sought a balance in terms of gender, age, hospitalization history, and housing circumstances (for detailed participant demographics see

Kidd et al., 2016). This study was reviewed and approved by the Research Ethics Board at the Centre for Addiction and Mental Health.

Each participant was interviewed at three time points over the course of 10 months. Participants spent several hours with research team members each time, completing an in-depth interview about their 
experiences living in the community, a survey, and other ethnographic data collection tasks such as taking the interviewer on a walking tour of their neighbourhood (see Kidd et al., 2016, for a detailed description of interview questions and survey items and measures).

With the consent of the participants, interviews were audio-recorded and transcribed verbatim. Field notes documented observations and informal interactions. All qualitative data were analyzed using the coding strategy articulated by Charmaz (1995), attending to the integration of ethnographic methods as recommended by Charmaz and Mitchell (2001; see Kidd et al., 2016 for a detailed description of study methods). Moreover, our analysis of the qualitative data was informed by an advisory committee of consumer/survivors (i.e., mental health service users). Drawing on past research, grey literature, and community advocacy on the issues of inclusion and community for people with psychiatric disabilities, the advisory committee was integral to shaping the analysis presented in this paper.

\section{FINDINGS}

\section{"I Don't Think It Should be Like Mr. Rogers"}

Our interview data reveal a disconnect between the neoliberal image of community as a specific geographic place outside of the hospital that offers easy access to security and belonging, and the reality experienced by the people with psychiatric disabilities. In particular, participants' narratives affirm that issues of inequity and exclusion continue to be prevalent in the lives of people with psychiatric disabilities (similar critiques have been raised elsewhere by activists with psychiatric disabilities; for example see Phoenix Rising, 1980-1990). Notably, we found that participants rarely used the term community when describing their lives and their hopes for the future. Despite the varied and complex ways in which the participants conceptualized community for themselves, neighbourhoods were rarely described as a significant source of social connection and meaning for people - again, in contrast with the neoliberal image or ideal of community. As a female participant of East Asian background noted when asked if she felt like she fit or belonged in her neighbourhood:

P: Yeah, yeah, I do. I don't feel out of place or anything.

I: Do you feel like it's a friendly neighbourhood, like do people say hi to each other on the street, or do you recognize people?

P: No, no, I don't recognize, no, not people per se. It's just the vendors, you know. . . . I don't think it should be like Mr. Rogers, you know. It shouldn't be that way, not totally. I do say hi at each vendor each time I buy something. I say hi and I pay or hi, I say hi to streetcars [driver] sometimes. Sometimes they say you're welcome, sometimes they don't.

In this quote, the participant describes how the idyllic view of the neigbourhood as imagined in the Mr. Rogers television show does not reflect her life. The above participant and others' descriptions of their neighbourhoods challenge the utopian vision of a neighbourhood as a place where people interact with their neighbours and feel a sense of belonging. Instead, for most participants, their neighbourhood or local community was largely a place where they had casual interactions with a few service people as part of running daily errands and purchasing things. 


\section{The Primacy of Poverty}

Also challenging the implicit, neoliberal notion of community as a place "out there" waiting to enjoin individuals into it was the theme of challenges and barriers related to poverty and social stigma. Many participants talked at length about how poverty, and the discrimination and stigma associated with poverty, impacted their ability to participate in daily life, make interpersonal connections, and live the kind of life they wanted to lead. In the following exchange, a woman of East Asian background touches on the challenges she faces:

I: When I say the word community what does that mean to you or what do you think of?

P: Places, people, things ... The doctor, for now.

I: Are there any significant relationships in your life you want to talk about, like family, friends, romantic partners?

P: No, not really, that's, no. ... Basically on my own, yeah, basically. ... I'm okay with that, I'm fine. ... But it's, it's more of a judgement what, my problem lately is my judgement of calling of what I'm going to buy each month....

I: So you're not really thinking about like romantic relationships or anything like that; that's not really a priority for you right now.

P: No, I have one but yeah, that's not a priority. No, priority is items and what I gotta do.

The challenges of poverty can make community-related priorities secondary. In the context of low disability support payments from the province, several participants articulated how difficult it is to focus on establishing an interpersonal sense of community when so much effort is required to budget properly and meet their basic needs.

A number of participants consistently reported that poverty reduced their opportunities to participate in consumer and leisure activities. Activities like going to movies or out for a meal were unaffordable because of most participants' limited budgets. Several participants also commented that they often lacked the clothes and the personal maintenance to feel comfortable in many mainstream consumer spaces like local bars, restaurants, and shops. The inability to access these spaces is important because consumerism plays a significant role in how community life is organized; paid activities are central to how many people interact with their neighbourhoods, meet new people (including potential romantic partners), and spend time with friends and family.

Access to safe and affordable housing was another poverty-related issue with significant impact on participants' movements and engagement within their environments. With limited housing options as a result of the location of services and subsidized housing, as well as serious affordability issues, most of the participants in our study found themselves living in poorer, more chaotic, and oftentimes unsafe downtown neighbourhoods. A woman from an African-Caribbean background commented:

The building I live in, it's basically a drug haven. It's like it's a 24 hour in and out. Security guard, we go through a lot of security companies because nobody wants to really stay there because people get really aggressive when they want their drugs and they can't come in. 
Safety and fear were major factors that shaped how participants, particularly female participants, structured their days and engaged with their neighbourhoods. The same respondent as above commented:

I feel safe in my neighbourhood, but I don't go out at night. I don’t feel safe when I walk at night.

It is relevant from a community perspective that many participants reported that they would not travel at night - a time when much of the "mainstream" population are going out and spending time (and money) in the city. As such, many participants were fundamentally disconnected from a whole portion of social life and community that was happening around them.

Not only were poor living conditions and safety concerns for many, but several participants now lived in neighbourhoods that were not where they lived before hospitalization or in neighbourhoods that were far away from their families. Poverty was also identified as a major barrier to relationship-building; participants were limited in the recreational activities they could do with friends, family, and romantic partners, and poverty also significantly impacted participants' ability to travel. With many participants' families living in the suburbs or out of the city, this was a major concern.

\section{Discrimination and Stigma}

The third broad area of concern related to notions of community and community integration identified by the participants in our study were the consequences of discrimination and stigma based on intersecting differences. Most participants reported experiencing discrimination and stigma associated with poverty, mental illness, and other intersecting factors such as race, culture, gender, and disability. Reflecting on the reaction she experienced within her family and community, a woman from an African-Caribbean background, for example, commented:

Most people feel it's a dangerous illness to have [schizophrenia]. People are afraid and scared of that. I lost all my friends. I don't have one friend. Once everybody found out I went to the mental hospital, everybody turned their back on me. So I don't have any friends. Just like my mom. My brother doesn't even talk to me really. He will come by, but when he wants something.

Some participants felt that the stigma and discrimination associated with mental illness prevented them from finding employment, housing, and from maintaining relationships. For instance, a woman of AfricanCaribbean background shared:

P: Society's the hardest one to get, feel accepted.

I: And why do you feel like that?

P: Because where I go, then they put me as mental and they don't understand [people who] are mental[ly ill], and people can be mental but not stupid. ... And not that I'm stupid, because I've got an education. One of the reasons why I'm not ... it's that I can't find job in my field right now. ... And then society knows that I'm mental, so I don't think they would want to have me to work for them. ... they want to push you into a corner; like society wants to push me in a corner and say, you belong in the insane world, you stay there.

Several participants, like this female participant of African-Caribbean background, talked about taking active steps to avoid disclosing their diagnosis or symptoms to others: 
When you have mental illness, people run from you. They're scared of you. That's why it's best if you don't tell them about it.

These statements counter the image of the community as a place of naturally occurring acceptance and belonging (Benbow, Rudnick, Forchuk, \& Edwards, 2014; Wahl, 1999).

\section{Cultural and Social Capital}

Related to the barriers of poverty and mental health discrimination and stigma, many participants had limited access to cultural capital and valued social roles. For several participants, finding employment was a central concern; this was as much about the value of making a contribution to society as it was about earning an income. This feeling can be understood in the context of how neo-liberal values of independence through paid employment have become central to being understood as a worthy citizen (Rose, 2000). For some participants, not having a job seemed to have a major impact on their self-image, social interactions, and community engagement. This experience is exemplified in the following exchange, in which a male participant of European background discusses his interactions with the owners of a bar he went to often:

I: Would you sit at the bar and chat with them?

P: No but they would say hello to me. They don't try to chat with me. They chat with other people. I don't have a job really, I don't have experiences like other people, like travelling and this and that, he discuss really different places because they travel because they got the money, they've been to LA or they've been to [Chicago] or whatever. ... He asked me if I was doing any shopping in the area; he was trying to make conversation. I said no. I was dressed nice. I had nice clothes on. ...

I: If he did start to chat you up would you feel comfortable talking about the experiences that you do have?

P: I have to explain that I'm living across the street. I wouldn't say I'm on disability. I would just say I live across the street inside the...I've never had to explain that to him; he's never asked that.

I: Do you feel like you do want to talk with people or you also happy not to talk?

P: I'm happy not to talk.

This participant articulates how it was hard for him to participate in a conversation with other people at a bar because he felt like he did not have any valued experiences to share with them. In this example, we see how despite being present in the "community," this participant's marginal economic position and stigmatized social identity prevented him from engaging as an equal and feeling included.

\section{DISCUSSION AND CONCLUSION: MOVING BEYOND “COMMUNITY” TO DISABILITY JUSTICE}

The most recent MHCC document makes some encouraging steps in acknowledging the role of systemic barriers to accessing community. In particular, the 2012 report provides more specific priorities with an emphasis on recovery, challenging discrimination and stigma, improving rights, investing in communitybased mental health services, and building capacity within institutions and workplaces to support positive 
mental health. The report also includes a discussion of the need for better housing and employment supports and the need for policy and institutions to be more sensitive to ethnoracial, gender, and sexual diversity.

Despite these encouraging directions, however, a closer examination of the strategy documents shows that the concept of community remains vague and undefined and that community often retains its image as a geographical place with inherent potential for inclusion and integration. Furthermore, within this vague and optimistic framing, communities are positioned as key actors in the recovery process - a positioning that can serve to downplay or obscure many of the fundamental and systemic issues that shape the lives of people with psychiatric disabilities that are beyond the power of communities to address. As our interview data reveal, community looks much different in reality than it does in most research and policy literature. The neighbourhoods where participants lived were rarely a source of belonging and social connection, and the interactions that most participants did have in their neighbourhoods were mostly in the context of purchasing goods and services (which was often hard to do because of poverty). Furthermore, many participants described how poverty and the stigma of mental illness limited their opportunities to engage in social interaction.

The people with psychiatric disabilities whom we interviewed articulated a desire for their practical needs to be met: housing, safety, economic security, stable and trusting relationships, supported employment opportunities, and the absence of stigma and discrimination. The most significant difference between the image and the reality of community is that whereas the benefits and solutions ascribed to community are implied and naturally occurring, the needs being expressed by the people with psychiatric disabilities require specific and sustained interventions and support.

As noted, neoliberal policy discourse not only outlines a specific type of solution to social welfare issues, but also advances a particular set of values and ways of thinking about responsibility. Arguably, neoliberal logics contribute to the notion that people with psychiatric disabilities are expected to learn to selfregulate and manage themselves into communities that structurally exclude them. Moreover, when people with psychiatric disabilities are unwilling or unable to integrate into exclusionary social realms, they may come to understand the problem to be them, rather than being in the logics of neoliberal communities - $\mathrm{a}$ self-blaming that came across in the interviews. In other words, neoliberal discourse stresses individual responsibility rather than addressing systemic issues that may make it difficult for people to feel included, to participate, and to ultimately "recover."

Our findings suggest an alternative framework for thinking about mental health policy, one informed by social justice and rights-based frameworks from the disability/mad research literature (Benbow et al., 2014; LeFrançois, Menzies, \& Reaume, 2013; Mingus, 2010; Morrow \& Weisser, 2012; Voronka et al., 2014). These perspectives emphasize the need to focus on challenging and removing systemic barriers, to address poverty as a central and underlying source of exclusion and marginalization, and to develop policies and interventions that give people with psychiatric disabilities the capacity to live a life of their choosing by recognizing individual needs. These perspectives challenge independence as a policy goal, arguing that well-being for all people is actually built on interdependence with others.

These perspectives are also underpinned by an understanding of intersectionality, that is, a recognition that "multiple social categories (e.g., race, ethnicity, gender, sexual orientation, socioeconomic status) intersect at the micro level of individual experience to reflect multiple interlocking systems of privilege and oppression 
at the macro, social-structural level" (Bowleg, 2012). Notably, our study provides some insights into the particular barriers that people with psychiatric disabilities who also belong to marginalized ethnocultural groups encounter in the community. Beyond the forces highlighted in this analysis, other analyses from this same project illustrate how forces like racism and ethnocentrism, as well as other cultural and religious dimensions of experience, intersect to produce particular experiences of community (see Virdee et al., 2016).

Issues of justice and equity should be placed front and centre in policy discussions about how to transform the mental health system, and policy discussions should move away from the vague language of community. Taking a social justice and rights-based approach would mean that a national mental health strategy would make structural goals its priority and provide specific insight into how such goals will be accomplished as part of addressing systemic barriers that people with psychiatric disabilities encounter.

An improved mental health policy framework would also make more specific recommendations about explicit policy changes and the bureaucratic and legislative bodies responsible for addressing particular issues. This would include identifying those issues and challenges outside the responsibility of the mental health system. Within the current MHCC strategy documents, vague and unspecified entities like "communities" and "transformed mental health systems" are being asked to tackle massive social problems like housing affordability, unemployment, the legacy of colonialism for Indigenous people, and racism. These issues are not ones that can be reasonably addressed through the work of communities or mental health systems alone (no matter how transformed). We acknowledge that social problems require multisectoral collaboration, but the risk of articulating such a broad framework for the mental health sector is that it obscures where the real change needs to occur. By being more specific and action-oriented, an improved framework could better identify specific challenges and resolutions within the mental health system, making the recommendations more actionable and ensuring greater accountability.

\section{REFERENCES}

Aubry, T., Flynn, R. J., Virley, B., \& Neri, J. (2013). Social role valorization in community mental health housing: Does it contribute to the community integration and life satisfaction of people with psychiatric disabilities? Journal of Community Psychology, 41, 218-235.

Benbow, S., Rudnick, A., Forchuk, C., \& Edwards, B. (2014). Using a capabilities approach to understand poverty and social exclusion of psychiatric survivors. Disability \& Society, 29(7), 1046-1060. https://doi.org/10.1080/ 09687599.2014 .902359

Bowleg, L. (2012). The problem with the phrase women and minorities: Intersectionality - an important theoretical framework for public health. American Journal of Public Health, 102(7), 1267-1273.

Canadian Mental Health Association. (1963). More for the mind: A study of psychiatric services in Canada. Toronto, ON: Author.

Charmaz, K. (1995). Grounded theory. In J. A. Smith, R. Harré, \& L. Van Langenhove (Eds.), Rethinking methods in psychology (pp. 27-49). London, England: Sage.

Charmaz, K., \& Mitchell, R. G. (2001). Grounded theory in ethnography. In P. Atkinson, A. Coffey, S. Delamont, J. Lofland, \& L. Lofland (Eds.), Handbook of ethnography (pp. 160-174). London, England: Sage.

Davis, S. (2014). Community mental health in Canada: Theory, policy, and practice. Vancouver: University of British Columbia Press.

Farone, D. (2006). Schizophrenia, community integration, and recovery. Social Work in Mental Health, 4, 21-36.

Goering, P., Wasylenki, D., \& Durbin, J. (2000). Canada's mental health system. International Journal of Law and Psychiatry, 23(3-4), 345-359. 
Grob, G. N. (1995). The paradox of deinstitutionalization. Society, 32, 51-59.

Kalathil, J., \& Faulkner, A. (2015, January-February). Racialisation and knowledge production: A critique of the report "Understanding psychosis and schizophrenia." Mental Health Today, 22-23.

Kennard, D. (2008). A view of the evolution of therapeutic communities for people suffering from psychosis. In J. Gale, A. Realpe, \& E. Pedriali (Eds.), Therapeutic communities for psychosis (pp. 3-15). New York, NY: Routledge.

Kennedy, J. F. (1963). Special message on mental illness and mental retardation, 5 February 1963. Papers of John F. Kennedy. Presidential Papers. President's Office Files. Legislative Files. Retrieved from https://www.jfklibrary. org/Asset-Viewer/Archives/JFKPOF-052-012.aspx

Kidd, S. (2013). From social experience to illness experience: Reviewing the psychological mechanisms linking psychosis with social context. Canadian Journal of Psychiatry, 58(1), 52-58.

Kidd, S. A., Frederick, T. J., Tarasoff, L., Virdee, G., Lurie, S., Davidson, L., . . McKenzie, K. (2016). Locating community among people with schizophrenia living in a diverse urban environment. American Journal of Psychiatric Rehabilitation, 19(2), 103-121.

Larner, W. (2000). Neo-liberalism: Policy, ideology, governmentality. Studies in Political Economy, 63, 5-25.

LeFrançois, B. A., Menzies, R. J., \& Reaume, G. (2013). Mad matters: A critical reader in Canadian mad studies. Toronto, ON: Canadian Scholars' Press.

Mental Health Commission of Canada. (2009). Toward recovery and well-being: A framework for a mental health strategy for Canada. Calgary, AB: Author.

Mental Health Commission of Canada. (2012). Changing directions, changing lives: The mental health strategy for Canada. Calgary, AB: Author.

Mingus, M. (2010). Changing the framework: Disability justice. Resist Newsletter, 19(6), 1-2.

Morrow, M., \& Weisser, J. (2012). Towards a social justice framework of mental health recovery. Studies in Social Justice, 6(1), 27-43.

Mulvale, G., Abelson, J., \& Goering, P. (2007). Mental health service delivery in Ontario, Canada: How do policy legacies shape prospects for reform? Health Economics, Policy and Law, 2, 363-389.

Novella, E. (2010). Mental health care and the politics of inclusion: A social systems account of psychiatric deinstitutionalization. Theoretical Medicine and Bioethics, 31(6), 411-427. https://doi.org/10.1007/ s11017-010-9155-8

Phoenix rising: The voice of the psychiatrized [magazine]. (1980-1990).

Poole, J. (2011). Behind the rhetoric: Mental health recovery in Ontario. Halifax, NS: Fernwood Publishing.

Psychosocial Rehabilitation Canada. (2010). Psychosocial rehabilitation practice standards and definitions for recoveryorientated services. Kingston, ON: PSR/RPS Canada.

Reaume, G. (2000). Remembrance of patients past: Patient life at the Toronto Hospital for the Insane, 1870-1940. Toronto, ON: University of Toronto Press.

Regehr, C., \& Glancy, G. (2014). Mental health social work in Canada. Toronto, ON: Oxford University Press.

Rose, N. (2000). Community, citizenship, and the Third Way. American Behavioral Scientist, 43(9), 1395-1411.

Royce-Davis, J. C. (2001). "It's the day-to-day living that matters": The meaning and process of community in the lives of a couple with significant psychiatric disabilities. American Journal of Community Psychology, 29(6), 807-832.

Scull, A. (2015). Madness in civilization: A cultural history of insanity, from the Bible to Freud, and from the madhouse to modern medicine. Princeton, NJ: Princeton University Press.

Smith, A. (2006). Heteropatriarchy and the three pillars of white supremacy. In INCITE! (Ed.), Color of violence: The INCITE! anthology (pp. 66-73). Boston, MA: South End Press.

Usar, O. (2014). Psychiatric system survivor/consumer advocacy: A critical literature review. Toronto, ON: Black Creek Community Health Centre.

Virdee, G., Frederick, T., Tarasoff, L. A., McKenzie, K., Davidson, L., \& Kidd, S. (2016). Exploring the contours of religion and spirituality in creating community: A focus on persons with psychosis. Journal of Community Psychology, 44(8), 1081-1087

Voronka, J., Wise Harris, D., Grant, J., Komaroff, J., Boyle, D., \& Kennedy, A. (2014). Un/helpful help and its discontents: Peer researchers paying attention to street life narratives to inform social work policy and practice. Social Work in Mental Health, 12(3), 249-279.

Wahl, O. F. (1999). Mental health consumers' experience of stigma. Schizophrenia Bulletin, 25(3), 467-478. 


\title{
La problématique de la « communauté » dans le domaine de la santé mentale
}

\author{
Tyler Frederick \\ University of Ontario Institute of Technology \\ Lesley A. Tarasoff \\ University of Toronto \\ Jijian Voronka \\ University of Windsor \\ Lucy Costa \\ Empowerment Council, Centre de toxicomanie et de santé mentale (CAMH) \\ Sean Kidd \\ Centre de toxicomanie et de santé mentale (CAMH) et University of Toronto
}

\begin{abstract}
RÉSUMÉ
Le concept de « communauté » est omniprésent dans les politiques, la recherche et la pratique en santé mentale au Canada. Malgré tout, sa signification est rarement définie. Dans le présent article, nous considérons le positionnement de la «communauté » dans le contexte historique et politique de la santé mentale au Canada, et nous révélons que celle-ci contraste avec les expériences vécues par les personnes ayant une incapacité psychiatrique. Nous soutenons que les politiques, la recherche et la pratique en matière de santé mentale devraient s'éloigner de la notion de communauté en faveur d'un cadre conceptuel qui tient compte des besoins fondamentaux, de la justice pour les personnes ayant une incapacité, des identités
\end{abstract}

Tyler Frederick, Faculté des sciences sociales et humaines, University of Ontario Institute of Technology, Oshawa (Ontario); Lesley A. Tarasoff, École de santé publique Dalla Lana, University of Toronto, Toronto (Ontario); Jijian Voronka, Faculté de service social, University of Windsor, Windsor (Ontario); Lucy Costa, Empowerment Council, Centre de toxicomanie et de santé mentale (CAMH), Toronto (Ontario); Sean Kidd, Centre de toxicomanie et de santé mentale (CAMH) et Département de psychiatrie, Université de Toronto, Toronto (Ontario).

Les auteurs souhaitent remercier tous les participants et participantes à la recherche, ainsi que les membres de l'équipe de recherche et ceux de l'Empowerment Council du Centre de toxicomanie et de santé mentale (CAMH) pour leur précieuse collaboration au projet de recherche élargi. La recherche a profité de l'appui financier de la Fondation ontarienne de la santé mentale et de la Fondation du Centre de toxicomanie et de santé mentale (CAMH).

La correspondance concernant cet article devrait être acheminée à Tyler Frederick, Faculty of Social Science and Humanities, University of Ontario Institute of Technology, 2000, Simcoe St. North, Oshawa (Ontario) L1H 7K4. Courriel : tyler.frederick@uoit.ca 
sociales intersectées et des forces structurelles qui influent sur la vie des personnes ayant une incapacité psychiatrique, et ce, au fur et à mesure que celles-ci se « rétablissent » à l'extérieur du milieu hospitalier.

Mots clés : communauté, participation communautaire, santé mentale, inclusion sociale, néolibéralisme

\begin{abstract}
The concept of "community" is ubiquitous in mental health policy, research, and practice in Canada; however, its meaning is rarely defined. In this paper, we consider the positioning of "community" within the Canadian historical and political mental health context and reveal that it contrasts with the lived experiences of people with psychiatric disabilities. We argue that mental health policy, research, and practice should move away from the term community in favour of a framework that addresses basic needs, disability justice, intersecting social identities, and the structural forces that impact the lives of people with psychiatric disabilities as they "recover" in settings outside of hospital.
\end{abstract}

Keywords: community, community participation, mental health, social inclusion, neoliberalism

Le concept de « communauté » est omniprésent dans les politiques, la recherche et la pratique en santé mentale au Canada. Malgré tout, sa signification est rarement précisée ou clairement définie. Dans le présent document, nous examinons la façon dont le concept de « communauté » a été positionné, tant dans le passé qu'au cours des dernières années, en mettant un accent particulier sur la stratégie en matière de santé mentale énoncée par la Commission de la santé mentale du Canada (CSMC) $(2009,2012)$. En nous appuyant sur des entrevues réalisées auprès de personnes ayant une incapacité psychiatrique en vue de connaître leurs opinions sur la communauté et son importance dans leur vie, nous démontrons combien le concept de la communauté dans les politiques, la recherche et la pratique en santé mentale diffère des expériences vécues par cette population. Plus précisément, nous avons constaté que le concept de communauté, tel que conçu professionnellement dans le secteur de la santé mentale, ne constitue pas une référence pertinente dans la vie des personnes ayant une incapacité psychiatrique.

De fait, les discussions sur la vie communautaire avec les participants et participantes ont principalement porté sur le caractère limitatif de la pauvreté. À partir de ces données ainsi que du travail historique et théorique des utilisateurs et utilisatrices de services eux-mêmes, nous soutenons que les politiques, la recherche et la pratique en santé mentale devraient s'éloigner de la notion de communauté en faveur d'un cadre conceptuel fondé sur la justice pour les personnes ayant une incapacité, axé sur l'élimination des entraves à la satisfaction des besoins fondamentaux (ex. : le logement), et qui reconnait le recoupement des identités sociales et les forces structurelles qui ont une incidence sur la vie des personnes ayant une incapacité psychiatrique au cours de leur « rétablissement » en dehors des hôpitaux.

\title{
La « communauté » dans le domaine de la santé mentale
}

Le concept de communauté dans le traitement des problèmes de santé mentale jouit d'une longue histoire en Occident, laquelle englobe les idées de communautés de rétablissement en Belgique, au XIV siècle, et de « traitement moral » chez les quakers, au XVIII siècle (Kennard, 2008). Le pouvoir de guérison des 
relations sociales et les répercussions sur la santé de l'environnement social et physique étaient au cœur de ces perspectives (Kennard, 2008). Ces premières idées ont jeté les bases de la montée en puissance de l'asile en tant que paradigme de traitement au cours des XIX ${ }^{\mathrm{e}}$ et $\mathrm{XX}^{\mathrm{e}}$ siècles. L'asile d'aliénés était imaginé comme un refuge communautaire et thérapeutique où une personne atteinte de maladie mentale pouvait aspirer à la tranquillité et aux soins nécessaires à son rétablissement. Malheureusement, plus souvent qu'autrement, les asiles et les institutions des XVIII ${ }^{\mathrm{e}}$ et XIX ${ }^{\mathrm{e}}$ siècles étaient davantage des lieux de ségrégation et de déshumanisation que des refuges (Davis, 2014; Mulvale, Abelson et Goering, 2007; Reaume, 2000; Regehr et Glancy, 2014).

À partir du milieu du XX ${ }^{\mathrm{e}}$ siècle, les idéaux normatifs de l'asile (peu importe à quel point leur conception était déficiente) furent davantage minés et dégradés par la médicalisation croissante de la maladie mentale et par le recours aux nouveaux produits pharmaceutiques émergents pour traiter les diagnostics comme la schizophrénie et la psychose. Cette tendance a fait en sorte que l'accent a été mis davantage sur les fondements biologiques de la maladie mentale et moins sur la valeur thérapeutique de la communauté dans le traitement des personnes ayant une incapacité psychiatrique (Novella, 2010). Le passage à la médicalisation, et la bureaucratisation correspondante des institutions dans les années 1960, a contribué à susciter des critiques du modèle d'asile d'aliénés, tant à l'intérieur qu'à l'extérieur du système de santé mentale (Goering, Wasylenki et Durbin, 2000; Grob, 1995; Scull, 2015). Parallèlement, les utilisateurs et utilisatrices des services de santé mentale s'organisaient pour lever le voile sur les discours troublants et les pratiques préoccupantes qui avaient cours dans le domaine de la psychiatrie (Usar, 2014).

Une nouvelle vision de la communauté mettant l'accent sur la valeur thérapeutique de l'inclusion dans la « communauté », et hors des établissements, des personnes ayant une incapacité psychiatrique était au cœur même de la critique croissante des établissements psychiatriques au Canada et aux États-Unis. L'optimisme qui sous-tendait ce virage vers les services communautaires de santé mentale trouve d'ailleurs écho dans l'allocution portant sur la Community Mental Health Act (loi sur les centres communautaires de santé mentale) prononcée par le président américain John F. Kennedy en 1963. Dans son discours, le président décrit comment la « miséricorde froide de l'isolement préventif » cédera la place à « la chaleur bienfaisante des préoccupations et des capacités communautaires » (Kennedy, 1963). Des idées semblables ont également fait leur chemin dans un rapport publié en 1963 par l'Association canadienne pour la santé mentale. Les auteurs du document intitulé More for the Mind plaidaient en faveur de l'intégration des services de santé mentale à même le système hospitalier comme moyen de délaisser progressivement les soins offerts en détention, et ce, afin de réduire au minimum les effets de la « dislocation » et de maintenir autant que possible la « continuité et la restauration sociale» (Association canadienne pour la santé mentale, 1963, p. 40).

Malheureusement, au Canada comme aux États-Unis, ce modèle précoce de santé mentale en milieu communautaire n'a jamais vu le jour (Davis, 2014). Parallèlement à cet élan en faveur de la prestation de services à l'extérieur des enceintes des hôpitaux psychiatriques, les forces économiques et politiques entraînaient une rationalisation rapide de ces centres hospitaliers sans la création correspondante de services communautaires destinés à les remplacer (Davis, 2014; Grob, 1995; Novella, 2010). Au Canada, le nombre de lits dans les hôpitaux psychiatriques a diminué de plus de 60 \% entre 1960 et 1976, alors que les dépenses consacrées aux services communautaires durant les années subséquentes sont demeurées relativement modestes. Ainsi, en 1990, le financement des services de santé mentale communautaires ne représentait que 
$3 \%$ des budgets provinciaux en matière de santé mentale (Goering et al., 2000). Collectivement désigné sous le nom de désinstitutionnalisation, ce processus, tout comme les échecs qui en résultent—entre autres le taux élevé d'itinérance, la pauvreté, le chômage, la victimisation, la stigmatisation publique et l'isolement social des personnes ayant une incapacité psychiatrique — sont amplement documentés (Davis, 2014; Grob, 1995; Regehr et Glancy, 2014).

\section{Une place quelque part là-bas : communautés néolibérales}

Malgré les échecs de l'ère de la désinstitutionnalisation au Canada, la communauté demeure un concept central des politiques, de la recherche et de la pratique en santé mentale. Bien que plus de 50 années se soient écoulées depuis sa première mention publique, et malgré son utilisation dans les grands discours politiques, le concept demeure bien souvent mal défini et la communauté conserve son image des années 1960 de place centrale, riche de promesses et vaguement conçue, indépendante des institutions, qui suscite un sentiment d'appartenance et d'inclusion chez toux ceux qui en font partie.

Le cadre stratégique national sur la santé mentale de la Commission de la santé mentale du Canada $(2009,2012)$ fournit un exemple concret de la manière dont le terme communauté est mis de l'avant dans les politiques au Canada. Dans les deux versions de la stratégie, le terme communauté est utilisé à plus de 200 reprises sans être officiellement défini ou traduit en termes opérationnels. En outre, la communauté y est décrite comme un espace physique et géographique, situé à l'extérieur d'une institution, qui offre des possibilités inhérentes d'appartenance sociale, ce qui fait écho aux idéaux des années 1960 décrits plus haut. Le document-cadre de 2009 stipule par exemple que « En tirant profit des forces individuelles, familiales, culturelles et communautaires, les gens ont le contrôle sur leur vie et sont soutenus de manière à pouvoir participer activement à leur processus de rétablissement et d'atteinte du bien-être ainsi qu'à pouvoir jouir d'une vie épanouissante au sein de leur communauté tout en cherchant à atteindre leur plein potentiel » (p. 21; italiques ajoutés). Ici, la communauté est un « lieu» hors contexte qui offre un potentiel intrinsèque d'appartenance sociale, et dans le cadre duquel les gens peuvent aspirer à l'autodépassement. Cette image reflète une vision néolibérale de la communauté qui est au cœur de la restructuration progressive de l'État via la consolidation des valeurs néolibérales, un processus qui a façonné les politiques publiques canadiennes (et celles d'autres pays) ces 30 dernières années.

Le néolibéralisme implique un virage vers un gouvernement plus petit, l'État agissant comme coordonnateur et facilitateur de diverses initiatives communautaires de bien-être social, plutôt qu'en être un fournisseur central et garant. Le néolibéralisme englobe non seulement la façon dont les directives politiques sont élaborées et gérées, mais aussi la manière dont les valeurs néolibérales d'indépendance, de rentabilité et d'austérité imprègnent le façonnement des valeurs idéologiques et des modes de gouvernance (voir Larner, 2000). Un élément moteur des modes de gouvernance et de l'idéologie néolibérale est qu'il est attendu des individus qu'ils apprennent à gérer eux-mêmes leurs problèmes, ceux qui n'y parviennent pas étant implicitement considérés comme des citoyens et citoyennes de moindre valeur et comme une menace potentielle à l'ordre social.

La notion de communauté comme solution de rechange naturelle à l'exclusion et à la marginalisation des personnes ayant une incapacité psychiatrique renvoie la responsabilité de l'inclusion aux communautés 
elles-mêmes et aux personnes et ne s'attaque aucunement aux problèmes d'ordre systémique comme l'oppression, le racisme et la pauvreté, lesquels ont une incidence directe sur la capacité des personnes de choisir leur mode de vie et leur lieu de résidence ou encore de participer à la vie communautaire. À cet égard, dans les mêmes 254 pages de la stratégie (Commission de la santé mentale du Canada, 2009, 2012) où le terme communauté figure à plus de 200 reprises, le vocable pauvreté apparaît moins de 25 fois et l'expression racisme moins de 10. De plus, la pauvreté y est largement décrite comme un facteur de risque de troubles de santé mentale, et il y est peu question du rôle important que joue la pauvreté dans l'organisation de la vie des personnes ayant une incapacité psychiatrique. Plus encore, comme l'ont décrit Morrow et Weisser (2012) et Poole (2011), l'accent mis sur le « rétablissement de la santé mentale » au cours de la dernière décennie a fait en sorte qu'une plus grande importance a été accordée à la biomédicalisation plutôt qu'à la poursuite de discussions sur les inégalités sociales. Ceci est important dans la mesure où le « rétablissement » est l'un des thèmes dominants des deux documents stratégiques, et que celui-ci est aujourd'hui aisément associé aux conceptions de communauté dans le cadre desquelles la « communauté » est le principal endroit où les patients et patientes recouvrent la santé.

Comparativement au document-cadre de 2009, le plus récent document de la CSMC (2012) convie à une réflexion plus spécifique sur la communauté et les obstacles systémiques comme le logement, l'emploi et la discrimination dans le cadre de ses orientations stratégiques pour un système de santé mentale communautaire transformé. Le document de 2012 renferme également des recommandations pour l'adoption d'un cadre des droits de la personne pour favoriser la gestion de la diversité et mieux faire entendre la voix des personnes atteintes de maladie mentale lors de la planification et de la prestation de services communautaires en santé mentale. Le document de 2012 propose également une liste d'indicateurs de résultats, y compris des indicateurs systémiques comme la hausse du taux d'emploi et l'augmentation du nombre de logements abordables.

Malgré ces mesures encourageantes, la notion de communauté conserve souvent son image confuse, présumée et optimiste. Par exemple, lorsqu'il est question des services en santé mentale, le document de 2012 stipule qu'en « appuyant les choix des personnes, en communiquant l'espoir et en réduisant la pratique de l'isolement et de la contention, on verra davantage de transitions menant vers une vie épanouissante dans la communauté » (p. 69). Cette déclaration fait écho à la vision optimiste qui se dégageait du discours de John F. Kennedy en 1963 selon laquelle l'espoir, le choix et le fait de ne pas être confiné dans un hôpital suffisent pour susciter un sentiment d'appartenance communautaire et pour acquérir la conviction de mener une vie utile au sein de la communauté. De plus, comme Smith (2006) le faisait remarquer, la rhétorique du choix est souvent invoquée dans le discours néolibéral pour laisser entendre que les individus jouissent du « libre choix ». Le paradigme du choix, affirme Smith, « repose essentiellement sur des notions individualistes et consuméristes de "libre" choix, lesquelles ne tiennent pas compte de l'ensemble des conditions sociales, économiques et politiques qui encadrent les soi-disant choix » que nous sommes contraints de faire (p. 127).

Le recours à la communauté dans le document de 2012 de la CSMC ne permet pas de bien saisir l'incidence du transfert de la responsabilité de l'État aux individus et aux communautés, et ne règle que partiellement la question des obstacles systémiques et de la discrimination. Soulignant la responsabilité qui incombe aux « collectivités » de soutenir le rétablissement des malades, par exemple, le document énonce ce qui suit : 
Sur le plan individuel et à l'échelle communautaire, on peut accomplir beaucoup de choses pour maintenir et améliorer la santé mentale. Certaines mesures toutes simples qui peuvent être facilement intégrées aux activités quotidiennes (comme faire un effort conscient pour créer des liens avec les personnes de l'entourage, être actif physiquement ou venir en aide à quelqu'un) se sont révélées efficaces pour contribuer au bienêtre mental des personnes. Pour favoriser une meilleure santé mentale, nous devons aussi nous efforcer de créer des communautés plus saines et d'éliminer les obstacles qui empêchent l'atteinte d'une meilleure santé mentale. Par exemple, en améliorant l'accès des familles à faible revenu aux loisirs, nous les aidons à devenir plus actives. (p. 22)

Cette déclaration illustre bien toute la complexité du discours qui entoure la communauté, la responsabilisation des communautés et des individus nous semblant intimement imbriquée aux problèmes systémiques. Bien que la reconnaissance des obstacles systémiques pour les familles à faible revenu soit quelque chose de grande valeur, il importe de remettre en cause ce sur quoi il faut agir. Dans le document, la reconnaissance des obstacles est présentée comme une question d'ordre secondaire, décrite en termes abstraits, ce qui fournit peu de directives sur la façon de s'attaquer concrètement à ces obstacles. De plus, les déclarations sur ce que les collectivités et les individus peuvent faire détournent l'attention du problème systémique fondamental qui est au cœur du problème décrit, à savoir la pauvreté. En raison des multiples façons dont la pauvreté façonne et organise la vie quotidienne, les familles à faible revenu se heurtent à des obstacles complexes pour accéder aux possibilités de loisirs qui peuvent difficilement être surmontés au moyen de simples initiatives d'accès (ex. : manque de temps pour rechercher les programmes appropriés, vêtements ou équipement non adéquats, stigmatisation et discrimination de la part des pairs et du personnel).

Autre exemple, le document de 2012 de la CSMC fait référence aux lignes directrices de Réadaptation psychosociale Canada (2010), soulignant le rôle que les communautés peuvent jouer dans le processus de rétablissement. Ces lignes directrices suggèrent que la communauté soit considérée comme un participant actif au processus de rétablissement : «Les individus et la famille, le cas échéant définis comme l'individu et la communauté, participent à la planification, à la mise en œuvre et à l'évaluation du service de soutien à la réadaptation psychosociale » (p. 12). Cependant, ces lignes directrices ne précisent pas comment la communauté est définie, ce que cela signifierait pour une communauté de s'impliquer dans la planification et la mise en œuvre du processus de rétablissement d'un individu, comment cette participation serait évaluée ou mesurée ou encore comment une collectivité pourrait être forcée d'être plus active s'il était déterminé qu'elle était jusqu'alors demeurée passive.

Les conceptions néolibérales de la communauté ne se reflètent pas seulement dans les documents de politique comme la stratégie de la CSMC; elles sont aussi aisément perceptibles dans les façons dont la communauté, l'intégration communautaire et la participation communautaire sont mesurées et comprises dans les documents de recherche sur la santé mentale et les services sociaux. Ces conceptualisations sont importantes parce qu'elles façonnent et sont façonnées par la manière dont les services sont fournis et dont les personnes ayant une incapacité psychiatrique sont comprises et évaluées par les cliniciens et les chercheurs. Dans son évaluation, Royce-Davis (2001) décrit trois grandes façons dont la communauté ou l'intégration communautaire est conceptualisée dans la documentation de recherche sur les services sociaux, à savoir : (a) la communauté comme une présence purement physique; (b) la communauté en tant que compétence nécessaire pour une vie communautaire indépendante; (c) la communauté telle que mesurée par des indicateurs comme la situation d'emploi ou le taux de réhospitalisation. Ces mesures reflètent et sous-tendent l'image 
de la communauté néolibérale en mettant l'accent sur l'autosuffisance et l'emploi, ce qui laisse entendre que l'intégration consiste simplement à vivre de façon autonome dans la communauté.

Plus récemment, les chercheurs ont tenté d'élaborer une conceptualisation et une mesure plus nuancées de la collectivité qui remettent en question une vision de la communauté réduite à sa situation géographique et qui mettent plutôt l'accent sur ses multiples dimensions, y compris ses composantes physiques, sociales, politiques, financières et psychologiques (Aubry, Flynn, Virley et Neri, 2013; Farone, 2006; Royce-Davis, 2001). On peut toutefois soutenir que nous devons prêter davantage l'oreille aux personnes ayant une incapacité psychiatrique pour vraiment comprendre ce que signifie la communauté et comment elle peut ou non faciliter le « rétablissement » de la santé mentale. D'après les entrevues que nous avons menées auprès d'un groupe de personnes ethniquement diversifiées, ayant une incapacité psychiatrique, il nous a été possible de constater que les notions de communauté et d'appartenance sont plus complexes que la vision utopique néolibérale présentant les quartiers et les villes comme des endroits qui recèlent un potentiel inhérent d'appartenance sociale.

\section{MÉTHODES}

\section{Étude de la communauté}

L'analyse qui suit s'appuie sur des entrevues réalisées auprès d'un groupe diversifié de personnes ayant une incapacité psychiatrique. Plus précisément, dans le cadre d'une étude de plus grande envergure explorant la signification que pouvaient revêtir la communauté et les expériences de participation communautaire chez les personnes ayant une incapacité psychiatrique (Kidd et al., 2016), nous avons interviewé 31 personnes qui avaient reçu un diagnostic de schizophrénie ou de maladie mentale grave du spectre psychotique et qui vivaient dans l'un des cinq quartiers du centre-ville de Toronto (Ontario). Les entrevues ont été réalisées entre les mois de septembre 2012 et de décembre 2013. Avec l'aide de prestataires de services issus de divers milieux (établissement hospitalier, service communautaire, hébergement à domicile), nous avons recruté des personnes provenant de quartiers ethniquement diversifiés où résident plusieurs personnes ayant une incapacité psychiatrique. Nous avons cherché à constituer un échantillon choisi à dessein, reflétant les principaux groupes ethnoculturels des quartiers ciblés, notamment les Afro-Antillais, les Asiatiques du sud, les Européens de race blanche et les Asiatiques de l'est. L'un des principaux objectifs était de mettre en valeur les expériences vécues par les personnes appartenant à ces divers groupes ethnoraciaux, la diversité ethnoraciale étant mal reflétée dans la littérature portant sur la communauté et le rétablissement de la santé mentale (Kalathil et Faulkner, 2015; Kidd, 2013). De plus, pour chacun des sous-groupes, nous nous sommes efforcés d'atteindre un équilibre en ce qui concerne le sexe, l'âge, les antécédents d'hospitalisation et les conditions de logement des participants et participantes (pour les données démographiques détaillées des participants et participantes, voir Kidd et al., 2016). La présente étude a été examinée et approuvée par le Comité d'éthique de la recherche du Centre de toxicomanie et de santé mentale.

Chaque participante ou participant a été interviewé à trois reprises sur une période de 10 mois. À chaque occasion, les participants et participantes ont passé plusieurs heures avec les membres de l'équipe de recherche pour réaliser une entrevue approfondie sur leurs expériences de vie dans la communauté, 
compléter un sondage et effectuer diverses tâches de collecte de données ethnographiques, par exemple la visite à pied avec l'intervieweur de leur quartier (voir Kidd et al., 2016, pour une description détaillée des questions d'entrevue ainsi que des éléments et mesures d'enquête).

Avec le consentement des participants et participantes, les entrevues ont été enregistrées et transcrites textuellement. Des notes de travail ont permis de documenter les observations et les interactions informelles. Toutes les données qualitatives ont été analysées à l'aide de la stratégie de codage développée par Charmaz (1995) en intégrant les méthodes ethnographiques recommandées par Charmaz et Mitchell (2001; voir Kidd et al., 2016 pour une description détaillée des méthodes d'étude). De plus, notre analyse des données qualitatives a bénéficié de l'éclairage d'un comité consultatif de personnes avec un vécu psychiatrique (c.à-d. des utilisateurs et utilisatrices des services de santé mentale). S'appuyant sur des recherches antérieures, la littérature grise et des rapports d'expertise d'organismes communautaires portant sur la communauté et l'inclusion sociale des personnes ayant une incapacité psychiatrique, le comité consultatif a joué un rôle essentiel dans l'élaboration de l'analyse présentée dans le présent article.

\section{RÉSULTATS}

\section{« Je ne pense pas que ça devrait être comme dans Mr. Rogers »}

Les données dérivées de nos entrevues révèlent un décalage entre l'image néolibérale de la communauté en tant que lieu géographique particulier, situé à l'extérieur des enceintes des centres hospitaliers, qui permet un accès facile à la sécurité et à l'appartenance sociale, et la réalité telle que vécue par les personnes ayant une incapacité psychiatrique. En particulier, les récits des participants et participantes illustrent que les problèmes d'iniquité et d'exclusion demeurent des entraves fréquentes dans la vie des personnes ayant une incapacité psychiatrique (des critiques similaires ont été soulevées ailleurs par des activistes ayant une incapacité psychiatrique; voir à titre d'exemple Phoenix Rising, 1980 à 1990). Notamment, nous avons constaté que les participants et participantes utilisaient rarement le terme communauté lorsqu'ils décrivaient leur vie et leurs attentes face à l'avenir. Malgré les façons variées et complexes dont les participants et participantes ont conceptualisé la communauté, les quartiers ont rarement été décrits comme une source importante de rapports sociaux et de sens pour les gens - ce qui contrastait encore une fois avec l'image néolibérale ou l'idéal de communauté. Comme l'a fait remarquer une participante originaire de l'Asie orientale lorsqu'on lui a demandé si elle se sentait à sa place ou encore si elle considérait appartenir à son quartier :

P : Oui, oui. Tout à fait. D'aucune manière je ne me sens comme si je n'étais pas à ma place ou quoi que ce soit du genre.

I : Avez-vous l'impression que c'est un quartier amical ? Les gens se saluent-ils dans la rue ? Reconnaissezvous les gens?

P: Non, non, je ne reconnais pas vraiment les gens. Vous savez, ce ne sont que des vendeurs. [. . .] Je ne pense pas que cela devrait être comme dans Mr. Rogers, vous savez. Cela ne devrait pas être comme ça, du moins pas tout à fait. Chaque fois que j'achète quelque chose, je salue le vendeur. Je dis bonjour et je paie mon achat ou je dis simplement bonjour. Parfois, il m'arrive de saluer les conducteurs de tramways. Parfois, ils me souhaitent la bienvenue. Parfois non. 
Dans cette citation, la participante décrit comment la vision idyllique du quartier telle qu'imaginée dans l'émission télévisée Mr. Rogers ne reflète pas sa vie. La description de la participante ci-dessus, tout comme celles d'autres participants et participantes, remet en question la vision utopique du quartier en tant qu'endroit où les gens interagissent avec leurs voisins et voisines et ressentent un sentiment d'appartenance. Au lieu de cela, pour la plupart des participants et participantes, leur quartier ou leur communauté était essentiellement un endroit où ils entretenaient des interactions informelles avec quelques préposés au service dans le cadre de leurs courses quotidiennes et de leurs emplettes.

\section{La prééminence de la pauvreté}

Le thème particulier des défis et des obstacles liés à la pauvreté et à la stigmatisation sociale a également remis en question la notion néolibérale implicite de la communauté en tant qu'espace « quelque part » n'attendant qu'à être rejoint par les individus. De nombreux participants et participantes ont longuement parlé de la façon dont la pauvreté, au même titre que la discrimination et la stigmatisation associées à la pauvreté, influait sur leur capacité de participer à la vie quotidienne, d'établir des relations interpersonnelles et de vivre le genre de vie qu'ils souhaitaient mener. Dans l'échange suivant, une femme originaire de l'Asie orientale discute des défis auxquels elle fait face :

I : Quand je dis le mot communauté, qu'est-ce que cela signifie pour vous ou à quoi pensez-vous ?

$\mathrm{P}$ : Les lieux, les gens, les choses [... .] Et le médecin en ce moment.

I : Y a-t-il des relations significatives dans votre vie comme la famille, les amis, les partenaires amoureux dont vous aimeriez parler?

P : Non, pas vraiment, non. [. . .] En gros je suis seule, oui, en gros. [...] Cela me convient, je suis bien. [...] Mais, c'est plutôt une question de jugement, mon problème dernièrement réside plutôt dans ma capacité à déterminer ce que je vais acheter chaque mois. [...]

I : Vous ne pensez donc pas vraiment aux relations amoureuses ou à autre chose qui pourrait s'en approcher; ce n'est pas vraiment une priorité pour vous en ce moment?

$P$ : Non, j'ai quelqu'un, mais effectivement ce n'est pas une priorité. Non, la priorité sont les biens et ce que je dois faire.

Les défis liés à la pauvreté peuvent faire passer les priorités communautaires au second plan. Étant donné la faiblesse du soutien financier accordé aux personnes ayant une incapacité par la province, plusieurs participants et participantes ont expliqué combien il leur était difficile de se concentrer sur le développement d'un sentiment interactionnel avec la communauté lorsque tant d'efforts sont nécessaires pour établir un budget adéquat et répondre à leurs besoins fondamentaux.

Certains participants et participantes ont indiqué à répétition que la pauvreté réduisait leurs possibilités de participer à des activités de consommation et de loisirs. Aller au cinéma ou manger au restaurant étaient considérées comme des activités inabordables en raison des budgets limités de la plupart des participants et participantes. Plusieurs entre eux ont également fait remarquer que leur tenue vestimentaire et leur hygiène personnelle étaient souvent inadéquates. Du coup, ils trouvaient embarrassant de fréquenter de nombreux espaces de consommation grand public tels que les bars, les restaurants et les magasins locaux. L'impossibilité 
d'accéder à ces lieux constitue un enjeu de grande importance du fait que la consommation joue un rôle important dans l'organisation de la vie communautaire. De fait, de l'avis de plusieurs, les activités rémunérées sont au cœur même des interactions qu'ils entretiennent avec les citoyens et citoyennes de leur quartier, des occasions qui leurs sont offertes de rencontrer de nouvelles personnes (y compris des partenaires amoureux potentiels) et du temps qu'ils s'accordent de passer avec des ami(e)s ou les membres de leurs familles.

L'accès à un logement sécuritaire et abordable est un autre problème lié à la pauvreté qui a une incidence importante sur les déplacements des participants et participantes et leur implication dans leur milieu. Vu les options de logement limitées du fait de l'emplacement des services et des logements subventionnés et en raison des problèmes criants d'abordabilité, la plupart des participants et participantes à notre étude se sont retrouvés dans des quartiers plus pauvres, plus désorganisés et, bien souvent, non sécuritaires. Une femme d'origine afro-antillaise a déclaré :

L'immeuble où j'habite est essentiellement un refuge pour le commerce de la drogue. C'est une porte tournante qui est en opération 24 heures sur 24. Nous changeons continuellement d'agence de sécurité. Personne ne veut vraiment occuper le poste. Cela s'explique du fait que les gens deviennent très agressifs quand ils veulent obtenir leurs drogues et qu'ils ne sont pas autorisés à entrer dans l'immeuble.

La sécurité et la peur sont des facteurs déterminants qui influencent la façon dont les participants et participantes, en particulier les femmes, organisent leurs journées et s'impliquent dans leur quartier. La même répondante que ci-dessus a fait les commentaires suivants :

Je me sens en sécurité dans mon quartier, mais je ne vais pas à l'extérieur le soir. Je ne me sens pas en sécurité quand je marche le soir.

D'un point de vue communautaire, il nous apparaît pertinent que de nombreux participants et participantes aient déclaré qu'ils ne se promèneraient jamais à l'extérieur la nuit — une période où une grande partie de la population « en général » sort pour passer du temps (et dépenser de l'argent) en ville. Ainsi, de nombreux participants et participantes se trouvent essentiellement déconnectés de toute une partie de la vie sociale et de la communauté qui les entourent.

Non seulement les conditions de vie déplorables et les problèmes de sécurité préoccupaient plusieurs participants et participantes, mais bon nombre d'entre eux vivaient désormais dans un quartier qui n'était pas le leur avant leur hospitalisation ou encore dans un quartier très loin de leur famille. La pauvreté a également été identifiée comme un obstacle majeur au développement de relations. Les participantes et participants étaient restreints dans les activités récréatives qu'ils pouvaient faire avec des amis et amies, les membres de leur famille et des partenaires amoureux. Par ailleurs, la pauvreté avait aussi une incidence considérable sur la capacité des participants et participantes à voyager. Enfin, les familles de nombreux participants et participantes étaient établies en banlieue ou à l'extérieur de la ville, ce qui constituait une préoccupation majeure pour nombre d'entre eux.

\section{Discrimination et stigmatisation}

Le troisième grand sujet de préoccupation lié aux notions de communauté et d'intégration communautaire identifié par les participants et participantes à notre étude était les conséquences de la discrimination et de la stigmatisation fondées sur les différences interconnectées. La plupart des participants et participantes ont 
déclaré avoir été victimes de discrimination et de stigmatisation associées à la pauvreté, à la maladie mentale et à d'autres facteurs interconnectés tels que la race, la culture, le sexe et les incapacités. Tout en réfléchissant aux différentes situations qu'elle a vécues au sein de sa famille et de sa communauté, une femme d'origine afro-antillaise a déclaré :

La plupart des gens estiment que c'est une maladie dangereuse [la schizophrénie]. Les gens ont peur de ça. J'ai perdu tous mes amis. Je n'ai pas d'amis. Lorsque les gens ont appris que j'étais allée à l'hôpital psychiatrique, ils m'ont tous tourné le dos. Je n'ai donc pas d'amis. Tout comme ma mère. Mon frère ne m'adresse plus vraiment la parole. Il vient me voir uniquement lorsqu'il a besoin de quelque chose.

Certains participants et participantes étaient d'avis que la stigmatisation et la discrimination associées à la maladie mentale les empêchaient de décrocher un emploi, de trouver un logement et d'entretenir des relations. Par exemple, une femme d'origine afro-antillaise a déclaré ce qui suit :

$\mathrm{P}$ : C'est la société qui est la plus difficile à convaincre, à façonner pour se sentir acceptée.

I : Pourquoi vous sentez-vous ainsi?

$\mathrm{P}$ : Parce que là où je vais, on me catégorise comme mentalement dérangée, le monde ne comprend pas [les personnes] qui souffrent de [maladie mentale], que les gens peuvent être mentalement dérangés sans pour autant être stupides. Je ne suis pas stupide. J'ai fait des études. Une des raisons pour lesquelles je ne le suis pas ..., c'est que je ne peux pas trouver d'emploi dans mon domaine à l'heure actuelle.[ ... .] Alors la société sait que je suis mentalement dérangée, et je ne pense pas qu'ils apprécieraient que je travaille pour eux. Ils veulent vous pousser dans un coin. La société veut me pousser dans un coin pour me dire, tu appartiens au monde des fous, restes-y.

Plusieurs participants et participantes, comme cette femme d'origine afro-caribéenne, ont parlé de la nécessité de prendre des mesures concrètes pour éviter de divulguer leur diagnostic ou leurs symptômes aux autres :

Lorsque vous souffrez d'une maladie mentale, les gens vous fuient. Ils ont peur de vous. C'est pourquoi il est préférable de ne pas leur en parler.

Les déclarations de la sorte vont à l'encontre de l'image de la communauté comme lieu naturel d'acceptation et d'appartenance (Benbow, Rudnick, Forchuk et Edwards, 2014; Wahl, 1999).

\section{Capital culturel et social}

En ce qui concerne les obstacles liés à la pauvreté ainsi que la discrimination et la stigmatisation en matière de santé mentale, plusieurs participants et participantes n'avaient qu'un accès limité au capital culturel et à des rôles sociaux de premier plan. Pour plusieurs d'entre eux, trouver un emploi constituait une préoccupation majeure; cela avait autant à voir avec la valeur réelle de contribuer positivement à la société que de la nécessité de gagner un revenu. Ce sentiment peut s'expliquer dans la mesure où les valeurs néolibérales d'indépendance, par le biais d'un emploi rémunéré, sont devenues capitales pour être perçu comme une citoyenne ou un citoyen méritant (Rose, 2000). Pour certains participants et participantes, le fait de ne pas occuper un emploi semblait avoir une incidence importante sur l'image qu'ils avaient d'eux-mêmes, leurs interactions sociales et leur engagement communautaire. Cette expérience est d'ailleurs clairement illustrée 
dans l'échange suivant, dans le cadre duquel un participant de sexe masculin, d'origine européenne, discute de la dynamique de ses interactions avec les propriétaires d'un bar qu'il fréquentait régulièrement :

I : Prendriez-vous place au bar pour discuter avec eux ?

P : Non, mais ils me salueraient. Ils n'essaient pas de discuter avec moi. Ils parlent avec d'autres personnes. Je n'ai pas vraiment d'emploi. Je ne suis pas riche d'expériences comme les autres, exemple les voyages, etc. Ils parlent de différents endroits parce qu'ils voyagent, parce qu'ils ont de l'argent. Ils sont allés à Los Angeles, à Chicago et ailleurs. [. . .] Il m'a demandé si je faisais du magasinage dans la région. Il tentait d'entretenir la conversation. J'ai dit non. J'étais bien habillé. Je portais de beaux vêtements. [. . .]

I : S'il commençait à discuter avec vous, seriez-vous à l'aise de parler de vos expériences ?

P : Je devrais expliquer que je vis de l'autre côté de la rue. Je ne dirais pas que je perçois des prestations d'invalidité. Je dirais simplement que je vis de l'autre côté de la rue, dans ... Je n'ai jamais eu à lui expliquer cela. Il ne m'a jamais posé ces questions.

I: Avez-vous le sentiment de vouloir parler aux gens ou êtes-vous heureux de ne pas le faire?

$\mathrm{P}$ : Je suis heureux de ne pas avoir à parler aux gens.

Ce participant explique à quel point il a été difficile pour lui de participer à une conversation avec d'autres personnes dans un bar parce qu'il estimait n'avoir aucune expérience précieuse à partager avec eux. Dans cet exemple, nous voyons comment, malgré le fait d'être présent dans la " communauté », la situation économique marginale du participant et son identité sociale stigmatisée l'ont empêché de s'engager d'égal à égal et de ne pas se sentir exclu.

\section{DISCUSSION ET CONCLUSION : ALLER AU-DELÀ DE LA «COMMUNAUTÉ » VERS LA JUSTICE POUR LES PERSONNES AYANT UNE INCAPACITÉ}

Le plus récent cadre conceptuel de la CSMC franchit des étapes encourageantes en reconnaissant l'incidence, sur l'accès à la collectivité, des obstacles systémiques. Plus particulièrement, le rapport de 2012 définit des priorités plus spécifiques axées sur le rétablissement, la lutte contre la discrimination et la stigmatisation, l'amélioration des droits, l'investissement dans les services de santé mentale communautaires et le renforcement des capacités au sein des établissements et des milieux de travail pour favoriser une santé mentale positive. Le rapport renferme également une discussion sur la nécessité d'améliorer les mesures de soutien au logement et à l'emploi et sur l'importance pour les politiques et les institutions de prendre davantage en compte la diversité ethnoraciale, sexuelle et de genre.

Malgré ces orientations encourageantes, un examen plus approfondi des documents stratégiques montre que le concept de communauté demeure vague et non défini, et que la communauté conserve souvent son image d'espace géographique, doté d'un potentiel inhérent d'inclusion et d'intégration. De plus, dans ce cadre vague et optimiste, les communautés se positionnent comme des acteurs clés du processus de rétablissement, un positionnement qui peut servir à minimiser ou à occulter bon nombre des problèmes fondamentaux et systémiques qui façonnent la vie des personnes ayant une incapacité psychiatrique et que les communautés ne sont pas en mesure de résoudre. Comme l'indiquent les données tirées de nos entrevues, la communauté semble, en réalité, être bien différente de ce qu'elle est dans la plupart des recherches et des documents 
politiques. Les quartiers où vivaient les participants et participantes étaient rarement une source d'appartenance et de rapports sociaux, et les interactions que la plupart des participants et participantes parvenaient à établir dans leurs quartiers se résumaient essentiellement à l'achat de biens et de services (ce qui était souvent rendu difficile en raison de leur niveau de pauvreté). Par ailleurs, de nombreux participants et participantes ont décrit comment la pauvreté et la stigmatisation de la maladie mentale limitaient leur capacité à s'engager dans des interactions sociales.

Les personnes ayant une incapacité psychiatrique que nous avons interviewées ont exprimé le désir que leurs besoins pratiques soient satisfaits, à savoir : le logement, la sécurité, la sécurité financière, les relations stables de confiance, les possibilités d'emploi encadré et l'absence de stigmatisation et de discrimination. La différence la plus significative entre l'image véhiculée de la communauté et la réalité est que si les avantages et les solutions attribués à la communauté sont implicites et naturels, les besoins exprimés par les personnes ayant une incapacité psychiatrique exigent quant à eux des interventions et un soutien à la fois spécifiques et soutenus.

Comme nous l'avons fait remarquer plus tôt, le discours politique néolibéral présente non seulement un type de solution spécifique aux enjeux liés au bien-être social, mais aussi un ensemble particulier de valeurs et de façons de penser la responsabilité. On peut soutenir que le raisonnement néolibéral contribue à l'idée que les personnes ayant une incapacité psychiatrique doivent apprendre à s'autoréguler et à s'organiser par elles-mêmes au sein des communautés qui tendent à les exclure de façon structurelle. De plus, lorsque les personnes ayant une incapacité psychiatrique ne sont pas disposées ou sont incapables de s'intégrer dans les domaines sociaux d'exclusion, elles peuvent en venir à la conclusion qu'elles sont la source du problème, plutôt que de se situer dans la logique des communautés néolibérales - cette façon de prendre sur elles le blâme est ressortie lors des entrevues. Autrement dit, le discours néolibéral met l'accent sur la responsabilité individuelle plutôt que sur la résolution des problèmes d'ordre systémique, de sorte qu'il peut être difficile pour les individus de se sentir inclus, de participer activement à la communauté et, au final, de se « rétablir ».

Nos observations suggèrent un cadre de réflexion alternatif pour penser la politique en matière de santé mentale, fondé sur la justice sociale et les droits de la personne, s'inspirant de la documentation portant sur l'incapacité/aliénation psychiatrique (Benbow et al., 2014; LeFrançois, Menzies et Reaume, 2013; Mingus, 2010; Morrow et Weisser, 2012; Voronka et al., 2014). Ces perspectives soulignent la nécessité de remettre en cause et d'éliminer les obstacles systémiques, de traiter la pauvreté comme une source fondamentale et sous-jacente d'exclusion et de marginalisation, et d'élaborer des politiques et des interventions qui donnent aux personnes ayant une incapacité psychiatrique la capacité de vivre la vie de leur choix par la reconnaissance des besoins individuels. Ces perspectives remettent en question l'indépendance en tant qu'objectif stratégique, faisant valoir que le bien-être de tous repose en fait sur l'interdépendance avec les autres.

Ces perspectives sont également étayées par une compréhension de l'intersectionnalité, c'est-à-dire la reconnaissance que « différentes catégories sociales (ex. : la race, l'ethnicité, le sexe, l'orientation sexuelle, le statut socioéconomique) se recoupent au micro-niveau de l'expérience individuelle pour refléter de multiples systèmes interreliés de privilège et d'oppression au niveau macro, social et structurel » (Bowleg, 2012). En particulier, notre étude donne un aperçu des obstacles particuliers que rencontrent dans la communauté les personnes ayant une incapacité psychiatrique appartenant à des groupes ethnoculturels marginalisés. Outre les forces mises en évidence dans cette analyse, d'autres analyses en lien avec ce même projet illustrent 
comment des pressions comme le racisme et l'ethnocentrisme, ainsi que d'autres dimensions culturelles et religieuses de l'expérience, s'entrecoupent pour produire des expériences communautaires particulières (voir Virdee et al., 2016).

Les questions de justice et d'équité devraient être au cœur des discussions politiques sur la façon de transformer le système de santé mentale, et les discussions sur les politiques devraient s'éloigner du langage vague de la communauté. L'adoption d'une approche fondée sur la justice sociale et les droits de la personne signifierait qu'un cadre stratégique national sur la santé mentale ferait des objectifs structurels sa priorité, et qu'il offrirait un aperçu précis de la façon dont ces objectifs seraient atteints en vue d'éliminer les obstacles systémiques auxquels font face les personnes ayant une incapacité psychiatrique.

Un cadre politique amélioré en matière de santé mentale permettrait également de formuler des recommandations plus précises sur les changements de politique explicites et les organes bureaucratiques et législatifs chargés de s'attaquer aux problématiques particulières. Cela inclurait l'identification des problèmes et des défis qui ne relèvent pas de la responsabilité du système de santé mentale. Dans les documents stratégiques actuels de la CSMC, on demande à des entités vagues et indéterminées comme les « communautés » et les « systèmes de santé mentale transformés » de s'attaquer à d'énormes problèmes sociaux comme l'abordabilité du logement, le chômage, l'héritage du colonialisme pour les peuples autochtones et le racisme. Ces problèmes ne peuvent pas être raisonnablement traités par le seul travail des communautés ou des systèmes de santé mentale (peu importe l'ampleur de la transformation). Nous reconnaissons que les problèmes sociaux exigent une collaboration multisectorielle, mais le risque de formuler un cadre aussi vaste pour le secteur de la santé mentale est que cela finisse par obscurcir là où doit s'opérer le véritable changement. En étant plus précis et davantage axé sur les actions concrètes, un cadre amélioré permettrait de mieux cerner les problèmes particuliers et les solutions spécifiques au sein du système de santé mentale, ce qui rendrait les recommandations plus pragmatiques et garantirait une plus grande responsabilisation.

\section{RÉFÉRENCES}

Association canadienne pour la santé mentale. (1963). More for the mind: A study of psychiatric services in Canada. Toronto, ON : Auteur.

Aubry, T., Flynn, R. J., Virley, B. et Neri, J. (2013). Social role valorization in community mental health housing: Does it contribute to the community integration and life satisfaction of people with psychiatric disabilities? Journal of Community Psychology, 41, 218-235.

Benbow, S., Rudnick, A., Forchuk, C. et Edwards, B. (2014). Using a capabilities approach to understand poverty and social exclusion of psychiatric survivors. Disability \& Society, 29(7), 1046-1060. https://doi.org/10.1080/0968 7599.2014.902359

Bowleg, L. (2012). The problem with the phrase women and minorities: Intersectionality-an important theoretical framework for public health. American Journal of Public Health, 102(7), 1267-1273.

Charmaz, K. (1995). Grounded theory. Dans J. A. Smith, R. Harré et L. Van Langenhove (dir.), Rethinking methods in psychology (p. 27-49). Londres, Angleterre : Sage.

Charmaz, K. et Mitchell, R. G. (2001). Grounded theory in ethnography. Dans P. Atkinson, A. Coffey, S. Delamont, J. Lofland et L. Lofland (dir.), Handbook of ethnography (p. 160-174). Londres, Angleterre : Sage.

Commission de la santé mentale du Canada. (2009). Vers le rétablissement et le bien-être : cadre pour une stratégie nationale en matière de santé mentale pour le Canada. Calgary, $\mathrm{AB}$ : Auteur.

Commission de la santé mentale du Canada. (2012). Changer les orientations, changer des vies : stratégie en matière de santé mentale pour le Canada. Calgary, $\mathrm{AB}$ : Auteur. 
Davis, S. (2014). Community mental health in Canada: Theory, policy, and practice. Vancouver : University of British Columbia Press.

Farone, D. (2006). Schizophrenia, community integration, and recovery. Social Work in Mental Health, 4, $21-36$.

Goering, P., Wasylenki, D. et Durbin, J. (2000). Canada's mental health system. International Journal of Law and Psychiatry, 23(3-4), 345-359.

Grob, G. N. (1995). The paradox of deinstitutionalization. Society, 32, 51-59.

Kalathil, J. et Faulkner, A. (2015, janvier-février). Racialisation and knowledge production: A critique of the report "Understanding psychosis and schizophrenia." Mental Health Today, 22-23.

Kennard, D. (2008). A view of the evolution of therapeutic communities for people suffering from psychosis. Dans J. Gale, A. Realpe et E. Pedriali (dir.), Therapeutic communities for psychosis (p. 3-15). New York, NY : Routledge.

Kennedy, J. F. (1963). Special message on mental illness and mental retardation, 5 February 1963. Papers of John F. Kennedy. Presidential Papers. President's Office Files. Legislative Files. Récupéré de https://www.jfklibrary.org/ Asset-Viewer/Archives/JFKPOF-052-012.aspx

Kidd, S. (2013). From social experience to illness experience: Reviewing the psychological mechanisms linking psychosis with social context. Revue canadienne de psychiatrie, 58(1), 52-58.

Kidd, S. A., Frederick, T. J., Tarasoff, L., Virdee, G., Lurie, S., Davidson, L., [. . .] McKenzie, K. (2016). Locating community among people with schizophrenia living in a diverse urban environment. American Journal of Psychiatric Rehabilitation, 19(2), 103-121.

Larner, W. (2000). Neo-liberalism: Policy, ideology, governmentality. Studies in Political Economy, 63, 5-25.

LeFrançois, B. A., Menzies, R. J. et Reaume, G. (2013). Mad matters: A critical reader in Canadian mad studies. Toronto, ON : Canadian Scholars' Press.

Mingus, M. (2010). Changing the framework: Disability justice. Resist Newsletter, 19(6), 1-2.

Morrow, M. et Weisser, J. (2012). Towards a social justice framework of mental health recovery. Studies in Social Justice, 6(1), 27-43.

Mulvale, G., Abelson, J. et Goering, P. (2007). Mental health service delivery in Ontario, Canada: How do policy legacies shape prospects for reform? Health Economics, Policy and Law, 2, 363-389.

Novella, E. (2010). Mental health care and the politics of inclusion: A social systems account of psychiatric deinstitutionalization. Theoretical Medicine and Bioethics, 31(6), 411-427. https://doi.org/10.1007/ s11017-010-9155-8

Phoenix rising: The voice of the psychiatrized [magazine]. (1980-1990).

Poole, J. (2011). Behind the rhetoric: Mental health recovery in Ontario. Halifax, Nouvelle-Écosse : Fernwood Publishing.

Réadaptation psychosociale Canada. (2010). Psychosocial rehabilitation practice standards and definitions for recoveryorientated services. Kingston, ON : PSR/RPS Canada.

Reaume, G. (2000). Remembrance of patients past: Patient life at the Toronto Hospital for the Insane, 1870-1940. Toront, ON : University of Toronto Press.

Regehr, C. et Glancy, G. (2014). Mental health social work in Canada. Toronto, ON : Oxford University Press.

Rose, N. (2000). Community, citizenship, and the Third Way. American Behavioral Scientist, 43(9), $1395-1411$.

Royce-Davis, J. C. (2001). "It's the day-to-day living that matters": The meaning and process of community in the lives of a couple with significant psychiatric disabilities. American Journal of Community Psychology, 29(6), 807-832.

Scull, A. (2015). Madness in civilization: A cultural history of insanity, from the Bible to Freud, and from the madhouse to modern medicine. Princeton, NJ : Princeton University Press.

Smith, A. (2006). Heteropatriarchy and the three pillars of white supremacy. Dans INCITE! (dir.), Color of violence: The INCITE! anthology (p. 66-73). Boston, MA : South End Press.

Usar, O. (2014). Psychiatric system survivor/consumer advocacy: A critical literature review. Toronto, ON : Black Creek Community Health Centre.

Virdee, G., Frederick, T., Tarasoff, L. A., McKenzie, K., Davidson, L. et Kidd, S. (2016). Exploring the contours of religion and spirituality in creating community: A focus on persons with psychosis. Journal of Community Psychology, 44(8), 1081-1087 
Voronka, J., Wise Harris, D., Grant, J., Komaroff, J., Boyle, D. et Kennedy, A. (2014). Un/helpful help and its discontents: Peer researchers paying attention to street life narratives to inform social work policy and practice. Social Work in Mental Health, 12(3), 249-279.

Wahl, O. F. (1999). Mental health consumers' experience of stigma. Schizophrenia Bulletin, 25(3), $467-478$. 